\title{
Coping With Stress: The Mitokine GDF-15 as a Biomarker of COVID-19 Severity
}

\begin{abstract}
Darakhshan Sohail Ahmed ${ }^{1,2}$, Stéphane Isnard 1,2,3, Carolina Berini ${ }^{1,2,4}$, John Lin ${ }^{1,2}$, Jean-Pierre Routy ${ }^{1,2,4 * t}$ and Léna Royston ${ }^{1,2,3,6 * t}$

1 Infectious Disease and Immunity in Global Health Program, Research Institute of McGill University Health Centre, Montreal, QC, Canada, ${ }^{2}$ Chronic Viral IIIness Service, McGill University Health Centre, Montreal, QC, Canada, ${ }^{3}$ CIHR Canadian HIV Trials Network, Vancouver, BC, Canada, ${ }^{4}$ CONICET - Universidad de Buenos Aires, Instituto de Investigaciones Biomédicas en Retrovirus y SIDA (INBIRS), Buenos Aires, Argentina, ${ }^{5}$ Division of Hematology, McGill University Health Centre, Montreal, QC, Canada, ${ }^{6}$ Division of Infectious Diseases, Geneva University Hospitals, Geneva, Switzerland
\end{abstract}

OPEN ACCESS

Edited by:

Vishwanath Venketaraman,

Western University of Health Sciences,

United States

Reviewed by:

Riem Gawish,

Medical University of Vienna, Austria Kathrin Eller,

Medical University of Graz, Austria

*Correspondence: Léna Royston

lena.royston@mail.mcgill.ca Jean-Pierre Routy

Jean-Pierre.Routy@mcgill.ca

${ }^{\dagger}$ These authors have contributed equally to this work

Specialty section: This article was submitted to Viral Immunology, a section of the journal

Frontiers in Immunology

Received: 22 November 2021 Accepted: 24 January 2022

Published: 16 February 2022

Citation:

Ahmed DS, Isnard $S$,

Berini C, Lin J, Routy J-P and Royston L (2022) Coping With Stress: The Mitokine GDF-15 as a Biomarker of COVID-19 Severity.

Front. Immunol. 13:820350. doi: 10.3389/fimmu.2022.820350
Growth differentiation factor 15 (GDF-15) is a transforming growth factor (TGF)- $\beta$ superfamily cytokine that plays a central role in metabolism regulation. Produced in response to mitochondrial stress, tissue damage or hypoxia, this cytokine has emerged as one of the strongest predictors of disease severity during inflammatory conditions, cancers and infections. Reports suggest that GDF-15 plays a tissue protective role via sympathetic and metabolic adaptation in the context of mitochondrial damage, although the exact mechanisms involved remain uncertain. In this review, we discuss the emergence of GDF-15 as a distinctive marker of viral infection severity, especially in the context of COVID-19. We will critically review the role of GDF-15 as an inflammationinduced mediator of disease tolerance, through metabolic and immune reprogramming. Finally, we discuss potential mechanisms of GDF-15 elevation during COVID-19 cytokine storm and its limitations. Altogether, this cytokine seems to be involved in disease tolerance to viral infections including SARS-CoV-2, paving the way for novel therapeutic interventions.

Keywords: GDF-15, COVID-19, biomarker, disease tolerance, adaptive metabolic response

\section{INTRODUCTION}

Discovered in 1990, growth differentiation factor 15 (GDF-15) is a stress-induced cytokine and a distant member of the transforming growth factor $\beta$ (TGF- $\beta$ ) superfamily (1-5). GDF-15 is the product of a gene on human chromosome 19p13.11-13.2 that was cloned in 1997 based on expression induction upon macrophage activation $(6,7)$. GDF-15 is considered as a major regulator of appetite (8-10) through its hindbrain receptor glial-derived neurotrophic factor receptor alphalike (GFRAL), and its plasma levels were found to be elevated in the context of obesity and diabetes (11). However, GDF-15 acts more as a regulator than an inducer of obesity, as illustrated in mouse models where GDF-15 overexpression and administration of recombinant GDF-15 decrease glucose intolerance and enhance lipid metabolism (12). In addition to a metabolic function, GDF-15 recently emerged as an inflammation-induced mediator of disease tolerance through cellular 
metabolic reprogramming in the context of infections (13). Indeed, animal models showed that during acute infections, GDF-15 promotes survival by stimulating hepatic sympathetic outflow, which further promotes cardioprotective triglyceride production (13). Altogether, this cytokine seems to play a role in disease tolerance in bacterial and viral infections to a certain extent, including in SARS-CoV-2 infection, which opens up a new avenue for therapeutic intervention (13).

\section{THE CELLULAR PRODUCTION OF GDF-15}

GDF-15 was first named macrophage inhibitory cytokine-1 (MIC-1) since it was originally characterized in activated macrophages. Since, GDF-15 has been shown to be a cell-stress response cytokine produced in many cell types (7). Under physiological conditions, GDF-15 is expressed in high levels in the placenta, prostate, and bladder as well as other organs such as liver, kidney, lymph nodes, muscles and colon $(14,15)$. Cell types reported to express GDF-15 include adipocytes, cardiomyocytes, skeletal and smooth muscle cells and macrophages (15). L'homme et al. recently identified saturated fatty acids (SFAs) as strong inducers of GDF-15 expression in macrophages (11). Endoplasmic reticulum (ER) stress was identified as a key trigger of SFAs-induced GDF-15 expression, through the unfolded protein response (UPR) at the cellular level via PKR-like ER kinase (PERK) (11). Such findings suggest a link between GDF15 and obesity, as SFAs-activated macrophages produce proinflammatory cytokines such as TNF- $\alpha$ and IL-1 $\beta$ (16). Additionally, GDF-15 was reported to be overexpressed in cancer cells of various origins, including predominantly prostatic, renal, urothelial, colorectal cancers and melanoma (17). Globally, GDF-15 is expressed in many different cell types from various organs, both in physiological and pathological conditions.

\section{CONDITIONS INDUCING INCREASED CIRCULATING LEVELS OF GDF-15}

High circulating levels of GDF-15 have been associated with chronic inflammatory conditions including renal, lung, liver and cardiovascular diseases (4-11), rheumatoid arthritis, cancers, anemia (18) and infections such as COVID-19. Under physiological conditions, elevated plasma levels of GDF-15 are also reported in older individuals, in late pregnancy and during strenuous exercise. The use of certain drugs such as metformin and colchicine has also been independently associated with increased levels of GDF-15 (12, 19, 20). Furthermore, GDF-15 appears as a marker for all-cause mortality in the elderly and constitutes a predictor of disease severity during bacterial and viral infections $(21,22)$. During inflammatory conditions, multiple cell types have been shown to release GDF-15, including endothelial cells, epithelial cells, vascular smooth muscle, macrophages and adipocytes (4, 23, 24). Taken together, GDF-15 appears to be released by multiple cell types both during acute and chronic low-grade inflammation.

\section{GDF-15 AS A MITOKINE DURING MITOCHONDRIAL DYSFUNCTION}

Mitochondria are intracellular organelles that constitute cellular "power stations" in all cell types and tissues. These organelles play key roles in many biological processes, such as programmed cell death, oxidative phosphorylation and energy production. Aging and inflammation have been shown to alter mitochondrial function $(3,25)$.

Upon stress, mitochondrial stress-induced cytokines (referred as mitokines) such as fibroblast growth factor 21 (FGF21) and GDF-15 are expressed (26). Mitokines act in an endocrine, paracrine and autocrine fashion depending on the tissue microenvironment, and have been shown to have both detrimental and protective effects depending on the stimulus intensity $(11,21)$. GDF-15 is involved in a biphasic (hermetic or U-curve) response via the GDF-15-STAT3 pathway $(2,21,27)$. Such hormetic paradoxical dose-response has been illustrated by Conte et al. who demonstrated that low plasma levels of GDF-15 were associated with healthy ageing, while higher levels were detrimental $(2,21)$. GDF-15 production has been associated with a low $\mathrm{NAD} / \mathrm{NADH}$ ratio, highlighting the influence of mitochondrial dysfunction on GDF-15 production (28), although ER stress and hypoxia were also shown to induce this cytokine $(2,29)$.

\section{CELLULAR MECHANISMS AND DOWNSTREAM SIGNALING PATHWAYS OF GDF-15}

There are still conflicting reports of the molecular mechanisms of GDF-15 at the cellular level $(2,30,31)$. It is established that GDF15 binds to the GDNF receptor family member GFRAL in the hindbrain, orchestrating its metabolic effects through the neurotransmitter cholecystokinin (CCK) and further reduces appetite and body weight through the RET coreceptor $(8,10$, $31,32)$. However, GFRAL is not expressed outside the brain, raising the possibility of alternative receptors involved in GDF15's immunomodulatory effects, especially through hematopoietic cells (31). As a member of the TGF $\beta$ family, it has been speculated that the peripheral effects of GDF-15 could be mediated through receptors of the TGF- $\beta /$ Smad signaling pathway $(2,31,33,34)$. Candidate receptors for GDF-15 are ALK-5/TGF- $\beta$ RII, TGF- $\beta$ RI, TGF- $\beta$ RII and the epithelial growth factor receptor ErbB2 (35-37). Recently, a new receptor for GDF-15, CD48, has been identified on Treg cells in a genetically-engineered mouse model (38). The GDF-15-CD48 interaction was shown to promote the propagation of Treg cells and indirectly upregulate forkhead transcription factor (Foxp3), 
enhancing the development of hepatocellular carcinoma (HCC) (38). This immunosuppressive tumor microenvironment was further shown to be altered by the introduction of monoclonal antibodies against GDF-15, which ultimately improved HCC control (38).

Downstream signaling of GDF-15 has been studied in different models. In a mouse model, GDF-15 has been shown to activate the PPAR $\beta / \delta$-AMPK-p53 pathway, enhancing the fatty acid oxidation and glucose uptake and reducing ER stress as well as inflammation (39). Interestingly, the antidiabetic effect of $\mathrm{PPAR} \beta / \delta$ was independent of the central GDF-15/GFRAL receptor in the hindbrain (39). Moreover, GDF-15 was reported to contribute to the increase in peroxisome proliferator-activated receptor-gamma coactivator (PGC)- $1 \alpha$ and lipin-1, involved in fatty acid metabolism induced by $\mathrm{PPAR} \beta / \delta$ activation (39). In the same animal model, the expression of GDF-15 was induced in the skeletal muscles via $\mathrm{PPAR} \beta / \delta$ agonist, mitigating inflammation and improving glucose tolerance (39). In another mouse model, GDF-15 induction through the PPAR $\gamma$ pathway plays a key role in tissue regeneration (40). In summary, hindbrain GFRAL acts as a receptor for GDF-15 and may explain part of its metabolic effects, however the mechanisms of its immunomodulatory effect remain to be determined.

\section{COPING WITH STRESS: GDF-15 IN THE CONTEXT OF HOST RESISTANCE AND DISEASE TOLERANCE}

Studies on GDF-15 levels during sepsis illustrate the hormetic role of GDF-15 during infection, with low levels being protective while high levels being associated with disease severity. Host survival during infection requires a delicate balance between host resistance, which is essential for detecting and eliminating pathogens, and disease tolerance, which is critical in minimizing collateral tissue damage (41). During infection, mortality is mainly determined by an exaggerated immune response rather than pathogen invasion, reflecting this dysregulation of the balance between defense and tolerance (42). Disease tolerance can be then perceived as "the beauty of compromise" as Mahatma Gandhi stated in his autobiography written by Louis Fisher in 1950, illustrated by T-cell exhaustion and metabolism reprogramming (Warburg effect) in cancer and chronic infections. GDF-15, which has emerged as an inflammation-induced mediator of disease tolerance through metabolic reprogramming, might then serve as a disease tolerance cytokine. The balance between disease tolerance and host-defense response is particularly relevant for COVID-19, due to the negative impact of a hyperinflammatory state in COVID19. This phenomenon is best illustrated in bats, which are welldocumented viral reservoirs and harbor many zoonotic coronaviruses. Despite high viral loads of highly pathogenic viruses in humans (as Ebola virus or SARS-CoV), infected bats exhibit no signs of disease $(43,44)$. Through unique immune characteristics, bats have an excellent balance between host defense and disease tolerance, allowing them to tamp excessive immune responses to pathogens (45) Effector molecules with known immunomodulatory effects such as GDF-15 might then be of great interest to restore a balanced response.

\section{ASSOCIATION BETWEEN HIGHER GDF-15 PLASMA LEVELS AND RESPIRATORY TRACT DISEASES}

Pulmonary epithelial cells constitute a major source of GDF-15 production $(46,47)$, especially during hypoxia (48) or upon exposure to various allergens, cigarette smoke (49) and air pollutants (50). In chronic obstructive pulmonary disease (COPD), which is associated with cigarette smoking, a positive association has been found between elevated levels of GDF-15 and exacerbation frequency as well as impairment of pulmonary function $(7,51-53)$. During pulmonary hypertension, GDF-15 has been associated with disease progression and mortality. Higher levels of GDF-15 have been linked with increased atrial pressure and pulmonary capillary wedge pressure, via induction by hypoxia and shear stress from the pulmonary vascular endothelial cells $(46,54)$. In addition, higher GDF-15 plasma levels were also found in alveolar epithelial cells in pulmonary fibrosis $(47,55)$. Tissue damage due to hyperoxia is also a strong inducer of GDF-15 secretion by pulmonary epithelial and endothelial cells and is linked with bronchopulmonary dysplasia (56). Conversely, GDF-15 demonstrated a protective role in ventilator-associated acute lung injury induced by platelets-neutrophils aggregates (48).

\section{THE SIGNIFICANCE OF GDF-15 IN VIRAL AND BACTERIAL INFECTIONS OUTSIDE COVID-19}

GDF-15 levels are significantly increased in patients with various infections and sepsis. Regarding hepatic viral infections, GDF-15 is associated with disease progression and enhanced viral replication (57-60). Hepatitis B virus (HBV)-linked HCC (57, 59-61) and liver fibrosis linked with hepatitis $\mathrm{C}$ virus (HCV) were both associated with GDF-15 elevation (58, 60, 62). GDF-15 was reported to be overexpressed in genetically engineered mice with acute exacerbations of COPD due to human rhinovirus $(\mathrm{RV})$, the most frequently detected virus in this context $(63,64)$. Moreover, in human airway epithelial cells as well as in a mouse model, GDF-15 was shown to promote RV replication and to increase viral-induced inflammation (64). This increased inflammation, which is known to be related to symptoms, could be partly explained through the impairment of interferon- $\gamma 1$ (IFN- $\gamma 1$ ) production by GDF-15 (64).

Although less studied, bacterial infections have also been associated with increased GDF-15 levels, both for Grampositive or Gram-negative bacteria $(13,65)$ Similarly, GDF-15 was found to be elevated in patients with septic shock and its plasma levels were correlated with increased mortality (66). On the other hand, GDF-15 knockout mice were shown to be 
protected against severe septic infection, with prolonged survival, and demonstrated better control over local infections $(61,66)$.

\section{GDF-15 AS A BIOMARKER COMING OF AGE IN THE COVID-19 PANDEMIC}

Several proteins have been identified as prognostic biomarkers in COVID-19 such as IL-6, IL-8, C-reactive protein (CRP), procalcitonin, ferritin, D-dimer, calprotectin, IFN- $\gamma$-induced protein 10 (IP-10), IFN- $\gamma$, TNF- $\alpha$, granulocyte monocytecolony stimulating factor (GM-CSF), and macrophage inflammatory protein (MIP) $1 \alpha$ and $1 \beta$ (66-71). However, only a handful of these cytokines were coined as prognostic markers associated with disease severity and progression in COVID-19 patients (reviewed in Table 1) (74). In addition, due to their very short half-lives, accurate cytokine measurements in the plasma remain difficult and need to be carefully interpreted.

TABLE 1 | Studies reporting an association between GDF-15 and COVID-19 severity.

\begin{tabular}{|c|c|c|c|c|c|c|c|}
\hline $\begin{array}{l}\text { Study design } \\
\text { and country }\end{array}$ & Demographics & $\begin{array}{l}\text { Comorbidities of studied } \\
\text { patients }\end{array}$ & Sample size (n) & $\begin{array}{l}\text { Patients } \\
\text { with } \\
\text { severe } \\
\text { Sx/MR }\end{array}$ & $\begin{array}{l}\text { Plasma GDF-15 } \\
\text { correlation with } \\
\text { patient status }\end{array}$ & $\begin{array}{c}\text { Other } \\
\text { markers } \\
\text { correlated } \\
\text { withn GDF-15 }\end{array}$ & Authors \\
\hline $\begin{array}{l}\text { Observational } \\
\text { study } \\
\text { Spain }\end{array}$ & $\begin{array}{l}\text { Hospitalized patients } \\
>60 \text { years } \\
\text { Mostly males }\end{array}$ & $\begin{array}{l}\text { DM, HTN, CVD, CKD, non- } \\
\text { asthma respiratory disease, } \\
\text { immunosuppression }\end{array}$ & 66 & $8 / 12.1 \%$ & $\begin{array}{l}\text { Severity of the } \\
\text { disease } \\
\text { Mortality }\end{array}$ & Calprotectin & $\begin{array}{l}\text { de } \\
\text { Gaudiana } \\
\text { et al. (68) }\end{array}$ \\
\hline $\begin{array}{l}\text { Prospective } \\
\text { observational } \\
\text { study } \\
\text { Norway }\end{array}$ & $>18$ years & $\begin{array}{l}\text { DM, HTN, CVD, CKD, } \\
\text { COPD, obesity }\end{array}$ & 123 & $35 / 28 \%$ & $\begin{array}{l}\text { Severity of the } \\
\text { disease at } \\
\text { baseline, day } 3 \text {, } \\
\text { day } 9 \\
\text { ICU admission } \\
\text { Mortality }\end{array}$ & Ferritin & $\begin{array}{l}\text { Myhre et } \\
\text { al. (70) }\end{array}$ \\
\hline $\begin{array}{l}\text { Single-center } \\
\text { retrospective } \\
\text { study } \\
\text { Germany }\end{array}$ & $\begin{array}{l}\text { Presence of ARDS } \\
\text { Median age } 58 \text { years } \\
77 \% \text { males }\end{array}$ & None & 39 & $15 / 38.8 \%$ & ICU admission & $\begin{array}{l}\text { IL-6, IL-10 and } \\
\text { CRP }\end{array}$ & $\begin{array}{l}\text { Notz et al. } \\
(71)\end{array}$ \\
\hline $\begin{array}{l}\text { Case-control } \\
\text { study }\end{array}$ & $\begin{array}{l}\text { Hospitalized patients } \\
\text { (moderate-severe } \\
\text { symptoms) Median age } 52 \\
-58 \text { years } \\
50 \% \text { females }\end{array}$ & None & $\begin{array}{l}80 \text { (patients with varying } \\
\text { disease severity and } \\
\text { Control) }\end{array}$ & $20 / 10 \%$ & $\begin{array}{l}\text { Hospitalization } \\
\text { rate } \\
\text { Mortality }\end{array}$ & C3a, galectin-9 & $\begin{array}{l}\text { Giron et } \\
\text { al. (69) }\end{array}$ \\
\hline $\begin{array}{l}\text { Cohort study } \\
\text { Sweden, USA }\end{array}$ & $\begin{array}{l}\text { Median age } 71 \text { years } \\
73 \% \text { males }\end{array}$ & $\begin{array}{l}\text { CVD, DM, HTN, stroke, } \\
\text { prior MI, current smoker, } \\
\text { obese }\end{array}$ & $\begin{array}{l}3999 \text { and } 1088 \text { (2 different } \\
\text { international cohorts- } \\
\text { ARISTOTLE and RE-LY } \\
\text { studies) }\end{array}$ & ND & Mortality risk & NT-proBNP & $\begin{array}{l}\text { Wallentin } \\
\text { et al. (72) }\end{array}$ \\
\hline $\begin{array}{l}\text { Cohort study } \\
\text { and } \\
\text { subcohort } \\
\text { study } \\
\text { London, UK }\end{array}$ & $\begin{array}{l}\text { Median age } 72.2 \text { years in } \\
\text { ESKD and COVID-19+ } \\
\text { group } \\
\text { Median age } 70.1 \text { years in } \\
\text { ESKD and COVID-19- } \\
\text { group }\end{array}$ & & $\begin{array}{l}\text { - } 51 \text { COVID-19 negative } \\
\text { ESKD patients } \\
\text { Subcohort B } \\
\text { - } 52 \text { COVID-19 positive } \\
\text { ESKD patients } \\
\text { - } 11 \text { COVID-19 negative } \\
\text { ESKD patients }\end{array}$ & $\begin{array}{l}41 / 46 \\
89 \%\end{array}$ & $\begin{array}{l}\text { Disease severity } \\
\text { Mortality risk }\end{array}$ & $\begin{array}{l}\text { IL18BP, CTSD } \\
\text { and KRT19 }\end{array}$ & $\begin{array}{l}\text { Gisby et } \\
\text { al. (73) }\end{array}$ \\
\hline $\begin{array}{l}\text { Retrospective } \\
\text { study } \\
\text { Foshan, } \\
\text { China }\end{array}$ & Median age 38-62 years & $\begin{array}{l}\text { HTN, DM, anemia, liver } \\
\text { cysts, respiratory diseases, } \\
\text { stroke, CVD, hyperlipidemia }\end{array}$ & $\begin{array}{l}440 \\
\text { (biomarkers analyzed in } 111 \\
\text { patients) }\end{array}$ & $\begin{array}{l}\text { Males= } 10 \\
(56 \%) \\
\text { Females= } \\
21(64 \%)\end{array}$ & $\begin{array}{l}\text { Severity and } \\
\text { progression of } \\
\text { disease }\end{array}$ & $\begin{array}{l}\text { IL-6, IL-8 and } \\
\text { CRP }\end{array}$ & $\begin{array}{l}\text { Teng et } \\
\text { al. (6) }\end{array}$ \\
\hline
\end{tabular}

GDF-15, growth differentiation factor 15; HIV, human immunodeficiency virus; HBV, hepatitis B virus; HRV, human rhinovirus; IL, interleukin; CRP, C-reactive protein; GM-CSF, granulocyte-macrophage colony-stimulating factor; TNF, tumor necrosis factor; IFN, interferon; DM, diabetes mellitus; CKD, chronic kidney disease; HTN, hypertension; MI, myocardial infarction; COPD, chronic obstructive pulmonary disease; CVD, cardiovascular disease; O2, oxygen; CLD, chronic liver disease; C3a, complement 3a; HCC, hepatocellular carcinoma; HBV, hepatitis B virus; CLD, chronic liver disease; CHB, chronic hepatitis B; ESKD, end-stage kidney disease; ARDS, adult respiratory distress syndrome; MR, mortality rate; (+), high plasma levels; hs-cTnT, high sensitive cardiac troponin T; NT-proBNP, N-terminal proB-type natriuretic peptide; $n$, sample size; UK, United Kingdom; CTSD, cathepsin D; KRT19, keratin 19: ICU, intensive care unit; O2, oxygen; Sx, symptoms; MR, mortality rate; ND, not described. 
Through the correlation of tissue damage, hypoxia and aging, GDF-15 emerged as a significant indicator of disease severity in individuals infected with SARS-CoV-2 (Table 1) $(6,71,73,75)$, specifically in patients with underlying lung pathologies such as COPD in older individuals $(42,46)$. An inverse correlation has been reported between GDF-15 plasma concentration and oxygen saturation, leading to stratification of disease severity in critically-ill patients with COVID 19 (70). Notz et al. demonstrated that both IL-6 and CRP were correlated with GDF-15 levels throughout the COVID-19 course, suggesting the significance of GDF-15 in inflammation (71). Among many inflammatory markers, increased levels of GDF-15 and ferritin were associated with poor outcomes in the intensive care unit (ICU) and hospitalized patients with COVID-19 (70). Similarly, de Guadiana et al. demonstrated a positive correlation between GDF-15 and ferritin, CRP, calprotectin, and D-dimer in hospitalized COVID-19 patients (68). GDF-15 and calprotectin were found to be the best prognostic markers in assessing the outcome in hospitalized patients infected with SARS-CoV-2 $(68,70)$. Taken together, higher plasma levels of GDF-15, cardiac biomarkers and higher levels of soluble angiotensin-converting enzyme 2 (sACE2) have been proposed for risk stratification in patients with COVID-19 $(67,72)$. In patients with end-stage kidney disease (ESKD) infected with SARS-CoV-2, Gisby et al. found more than 200 proteins differentially expressed compared to non-infected controls, 67 of which were linked to an increased risk of mortality (73). Among various proteins known as contributors of inflammation and organ damage, GDF-15 was one of the top 12 cytokines/ chemokines on the list (73).

In another study, out of 440 potential biomarkers tested by antibody array profile and confirmed by enzyme-linked immunosorbent assay (ELISA), GDF-15 was found to be consistently and statistically correlated with the severity and the progression of COVID-19 (6). Dynamic changes of GDF-15 levels reflected disease progression, with high levels linked to symptom deterioration, followed by a dramatic decline in plasma GDF-15 levels at the time of clinical and radiological improvement and discharge (6). This study indicates that GDF-15 could be used as a predictor of the progression of the disease (Table 1) (6).

\section{IMMUNOMODULATORY FUNCTION OF GDF-15 DURING COVID-19}

It has been established that the pathogenesis of severe COVID-19 involves the hyperactivation of the immune response leading to a life-threatening 'cytokine storm' (76). This clinical syndrome can be induced by both infectious and non-infectious causes, and is characterized by an imbalance between cytokine production and activation of the immune response leading to a hyperinflammatory state and multiorgan failure. Extensive cytokine surges, such as IL-1, IL-6, IL-18, TNF $\alpha$ and IFN- $\gamma$ (76) triggered by various pathogens (77-79), induce a cytokine release syndrome (CRS) leading to widespread inflammation and considerable tissue damage $(76,80)$. This further leads to endothelial cell dysfunction, multiorgan failure, disseminated intravascular coagulation (DIC), acute respiratory distress syndrome and alteration in iron homeostasis $(74,76,81)$. COVID-19 mortality is directly correlated with the elevation of cytokines (82), in which monocyte/macrophages, neutrophils, and natural killer $(\mathrm{NK})$ cells seem to play a role $(74,76)$. Innate and adaptive immune responses have also been shown to be uncontrolled, specifically in virus-infected cells (76). In the case of COVID-19, a small proportion of patients affected by severe disease were shown to present with underlying dysregulated host innate response, inducing a hyperinflammatory syndrome (83). In addition, a cytokine storm is observed more frequently in elderly patients and correlates with rapid deterioration during COVID-19 $(75,84)$. Severe outcomes have been particularly observed in patients with coexisting chronic inflammatory conditions, such as hypertension, diabetes, and obesity, which are in turn linked with elevated plasma GDF-15 levels (76). Cytokine storm-induced GDF-15 elevation was shown to protect against cardiovascular alterations in a mouse model, however, it remains unknown whether this effect is present in COVID-19 patients (13).

Endothelial dysfunction is also a hallmark of COVID-19 and has been linked with oxidative stress $(74,85)$. The hyperactivity of the angiotensin-converting enzyme (ACE)-Angiotensin (Ang) II- Angiotensin type 1 receptor (AT1) axis of the classical reninAng system was shown to contribute to the coagulopathy observed in patients with COVID-19 (74). In addition, endothelial cells constitute a direct target of SARS-CoV-2, which further contributes to endothelial dysfunction. The SARS-CoV-2 cellular receptor ACE2 is heavily expressed in vital organs such as the lung, liver, kidneys, heart, and blood vessels, especially in type II pneumocytes in the lungs (74). Upon binding, the virus is internalized through the endogenous ACE2 receptor through the $\mathrm{S} 1$ domain of the spike glycoprotein (S) (74). S2 domains expressed on the SARS-CoV-2-infected cells then cause a fusion between ACE2-positive neighboring cells and triggers the formation of multinucleated syncytial pneumocytes $(74,86)$. AT1 receptor plays a pivotal role in oxidative stress through numerous intracellular signaling pathways. The endothelial cell damage causes recruitment of inflammatory cells and overproduction of cytokines and endothelialitis resulting in microcirculatory vascular changes in the various tissues (74).. Due to its high expression in endothelial cells and its induction upon hypoxia, GDF-15 might play a role in COVID19 endothelialitis $(46,54,70)$. GDF-15 is secreted from the epithelial and endothelial cells as a result of inflammation and oxidative stress in COVID-19. GDF-15 may exert its effect directly on immune cells as well as via the central GDF-15/ GFRAL receptor in the hindbrain (74). The high amount of IL-6 secreted by activated macrophages trigger production of IL-17, which results in excessive immune activation and intense widespread inflammation (50) (Figure 1). Despite its involvement in immune tolerance, GDF-15 elevation seems to be overwhelmed by uncontrolled inflammation in certain patients with COVID-19, leading to vascular pathologies in vital organs $(74,87,88)$. 


\section{Contribution of GDF15 signaling pathway in COVID-19 pathogenesis}
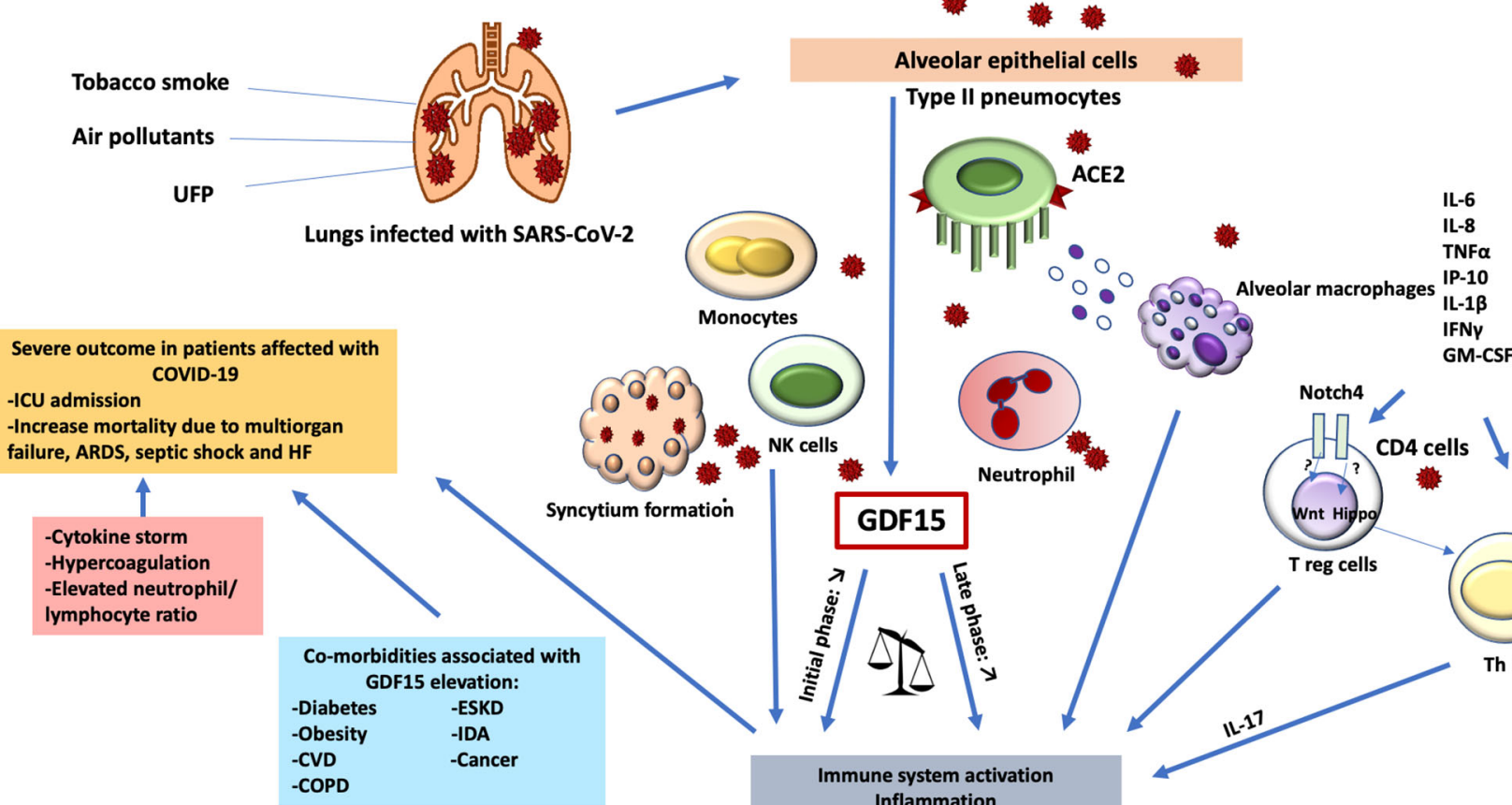

-ICU admission

-Increase mortality due to multiorgan

failure, ARDS, septic shock and $H F$

Cytokine storm

Hypercoagulation

-Elevated neutrophil/

mphocyte ratio

FIGURE 1 Contribution of a GDF-15 signaling pathway in COVID-19 pathogenesis. Lungs infected with SARS-CoV-2 lead to tissue damage, hypoxia, and endothelialitis. Tobacco smoke, ultrafine particles, and air pollutants act as a co-stimulant in the direct release of GDF15 in the lung epithelial cells. The virus enters the host cell via ACE2 on type II pneumocytes causing the recruitment of leucocytes, hence, elevated innate immune response. SARS-COV-2 also causes direct endothelialitis after the destruction of the alveolar epithelia. The transmigration of leucocytes causes a massive release of proinflammatory cytokines IL-6, IL-8, TNF alpha, IP-10, IL-1beta, IFN gamma, GM-CSF, and Notch pathway. The hippo pathway favors IL-17 differentiation and the Wnt pathway inhibits Treg suppressor function mediated by GDF15 resulting in overwhelming immune system activation. Together with the formation of the syncytium, hyperactivation of immune response commenced leading to cytokine storm, hypercoagulation and elevated neutrophils-lymphocytes ratio critical in severe outcomes in patients affected with SARS-COV-2 especially with comorbidities. GDF, growth differentiation factor; IL, interleukin; ARDS, acute respiratory distress syndrome; ACE, angiotensin-converting enzyme; UFP, ultrafine particles; HF, heart failure; COPD, chronic obstructive pulmonary disease; CVD, cardiovascular diseases; CD, cluster differentiation; GM-CSF, granulocyte monocyte-colony stimulating factor; SARS-CoV-2, severe acute respiratory syndrome coronavirus 2; ESKD, end-stage kidney disease; IDA, iron-deficiency anemia; T reg, regulatory T cells; ICU, intensive care unit; NK cells, natural killer cells.

\section{GDF-15, IRON METABOLISM AND COVID 19}

One of the proposed mechanisms of oxidative stress and hyperinflammatory state in COVID-19 is dysregulation of iron metabolism (74). Plasma GDF-15 levels have been found to be high in iron deficiency anemia, anemia of chronic disease and iron overloading anemia such as $\beta$-thalassemia (89-91). GDF-15 is inversely associated with hepcidin, a key regulator in systemic iron homeostasis in mammals $(74,90,92)$, expediting intestinal iron absorption leading to iron overload $(93,94)$. Inflammation, which is also a hallmark of chronic anemia, increases the expression of GDF-15 in several pathologies such as ESKD, cancers, diabetes and cardiovascular diseases $(73,91,94,95)$ (Table 1). GDF-15 has emerged as an immune modulator in older patients with anemia in COVID-19 and its role is critical in ferroptosis and dysregulated hematopoiesis in the erythroid cell lineage $(74,96)$.
Iron deficiency anemia is very common in patients with ESKD (97). In one cross-sectional study in South Africa, GDF15 was found to be a predictor of iron deficiency anemia in early renal disease (91). GDF-15 is also associated with a decline in renal function in chronic renal diseases (98). The iron overload associated with overexpression of GDF-15 in inflammatory states could lead to increase ferritin, another crucial biomarker in stratifying disease severity in COVID-19 (Table 1). Altogether, this could partly explain the relationship between the elevated plasma GDF-15 levels, underlying anemia, and severity of COVID-19 in chronic inflammatory conditions especially $\operatorname{ESKD}(73,74)$.

Recently, high-dose iron chelation has been approved by FDA as adjuvant therapy in critically-ill patients infected with SARSCOV-2 (18). In addition to lowering iron levels, iron chelating therapy demonstrated antiviral and antifibrotic activity while improving endothelialitis and innate immunity (99). There is some evidence supporting treatment of COVID-19-associated- 
mucormycosis with iron chelators (100), although more studies are needed to fully understand the beneficial effects of this adjuvant therapy.

GDF-15 could therefore potentially be used as a critical biomarker to predict the early use of iron-chelating therapy in patients with COVID-19 with co-existing subclinical inflammation and complications.

\section{CONCLUSION}

Altogether, high levels of GDF-15, a stress-related cytokine, have been associated with the progression and severity of various conditions including COVID-19. Based on our literature review, GDF-15 represents a clinically relevant marker for risk stratification or screening for severe COVID-19 (41). The use of GDF-15 as a biomarker could also enable the identification and optimal timing of the most appropriate therapies in patients with COVID-19 (87). The role of GDF-15 in viral pathogenesis, notably COVID-19, seems to be context-dependent, spanning from a promotor of disease tolerance in the early phase of infection to a detrimental actor in certain patients with cytokine storm. Furthermore, the potential outcome of treating early COVID-19 patients with recombinant GDF-15 could be explored in further studies.

\section{REFERENCES}

1. Coll AP, Chen M, Taskar P, Rimmington D, Patel S, Tadross JA, et al. GDF15 Mediates the Effects of Metformin on Body Weight and Energy Balance. Nature (2020) 578(7795):444-8. doi: 10.1038/s41586-019-1911-y

2. Conte M, Martucci M, Mosconi G, Chiariello A, Cappuccilli M, Totti V, et al. GDF15 Plasma Level Is Inversely Associated With Level of Physical Activity and Correlates With Markers of Inflammation and Muscle Weakness. Front Immunol (2020) 11:915. doi: 10.3389/fimmu.2020.00915

3. Lockhart SM, O'Rahilly S. The Wasting Hormone GDF15 Frees Up Fat to Fight Infection. Nat Metab (2019) 1(10):935-6. doi: 10.1038/s42255019-0131-y

4. Tsai V, Lin S, Brown D, Salis A, Breit S. Anorexia-cachexia and Obesity Treatment may be Two Sides of the Same Coin: Role of the TGF-B Superfamily Cytokine MIC-1/Gdf15. Int J Obes (2016) 40(2):193-7. doi: 10.1038/ ijo.2015.242

5. Wynn TA, Chawla A, Pollard JW. Macrophage Biology in Development, Homeostasis and Disease. Nature (2013) 496(7446):445-55. doi: 10.1038/ nature 12034

6. Teng X, Zhang J, Shi Y, Liu Y, Yang Y, He J, et al. Comprehensive Profiling of Inflammatory Factors Revealed That Growth Differentiation Factor-15 Is an Indicator of Disease Severity in COVID-19 Patients. Front Immunol (2021) 12. doi: 10.3389/fimmu.2021.662465

7. Bootcov MR, Bauskin AR, Valenzuela SM, Moore AG, Bansal M, He XY, et al. MIC-1, A Novel Macrophage Inhibitory Cytokine, Is a Divergent Member of the TGF- $\beta$ Superfamily. Proc Natl Acad Sci (1997) 94(21):11514-9. doi: 10.1073/pnas.94.21.11514

8. Emmerson PJ, Wang F, Du Y, Liu Q, Pickard RT, Gonciarz MD, et al. The Metabolic Effects of GDF15 Are Mediated by the Orphan Receptor GFRAL. Nat Med (2017) 23(10):1215. doi: 10.1038/nm.4393

9. Hsu J-Y, Crawley S, Chen M, Ayupova DA, Lindhout DA, Higbee J, et al. NonHomeostatic Body Weight Regulation Through a Brainstem-Restricted Receptor for GDF15. Nature (2017) 550(7675):255-9. doi: 10.1038/nature24042

\section{AUTHOR CONTRIBUTIONS}

DA contributed to the planning of the manuscript, reviewed the literature and wrote the first draft of the manuscript. SI, JL and $\mathrm{CB}$ reviewed the first draft and approved the final draft of the manuscript. J-PR and LR contributed equally, conceived and designed the manuscript, contributed to the literature review, reviewed the manuscript drafts, and approved the final version. DA, SI, JL, CB, LR, and J-PR provided critical revision of the manuscript. All authors approved it for publication.

\section{FUNDING}

Our research is funded by the Fonds de la Recherche QuébecSanté (FRQ-S): Réseau SIDA/Maladies infectieuses and Thérapie cellulaire; the Canadian Institutes of Health Research (CIHR; grants MOP 103230 and PTJ 166049); the Vaccines \& Immunotherapies Core of the CIHR Canadian HIV Trials Network (CTN; CTN PT038); CIHR- funded Canadian HIV Cure Enterprise (CanCURE) Team Grant HB2-164064. LR is supported by a Postdoc mobility grant of the Swiss National Science Foundation, Switzerland and a research fellowship from the Canadian Institutes of Health Research (CIHR) HIV trial network (CTN). SI is supported by research fellowships from Fonds de la Recherche Quebec-Science (FRQ-S) and the CIHR/ CTN. J-PR is the holder of the Louis Lowenstein Chair in Hematology and Oncology, McGill University.

10. Yang L, Chang C-C, Sun Z, Madsen D, Zhu H, Padkjær SB, et al. GFRAL is the Receptor for GDF15 and Is Required for the Anti-Obesity Effects of the Ligand. Nat Med (2017) 23(10):1158. doi: 10.1038/nm.4394

11. L'homme L, Sermikli BP, Staels B, Piette J, Legrand-Poels S, Dombrowicz D. Saturated Fatty Acids Promote GDF15 Expression in Human Macrophages Through the PERK/eIF2/CHOP Signaling Pathway. Nutrients (2020) 12 (12):3771. doi: 10.3390/nu12123771

12. Ouyang J, Isnard S, Lin J, Fombuena B, Peng X, Chen Y, et al. GDF-15 as a Weight Watcher for Diabetic and Non-Diabetic People Treated With Metformin. Front Endocrinol (2020) 11:911. doi: 10.3389/fendo.2020. 581839

13. Luan HH, Wang A, Hilliard BK, Carvalho F, Rosen CE, Ahasic AM, et al. GDF15 Is an Inflammation-Induced Central Mediator of Tissue Tolerance. Cell (2019) 178(5):1231-44.e11. doi: 10.1016/j.cell.2019.07.033

14. Johann K, Kleinert M, Klaus S. The Role of GDF15 as a Myomitokine. Cells (2021) 10(11):2990. doi: 10.3390/cells10112990

15. Wischhusen J, Melero I, Fridman WH. Growth/differentiation Factor-15 (GDF-15): From Biomarker to Novel Targetable Immune Checkpoint. Front Immunol (2020) 11:951. doi: 10.3389/fimmu.2020.00951

16. Håversen L, Danielsson KN, Fogelstrand L, Wiklund O. Induction of Proinflammatory Cytokines by Long-Chain Saturated Fatty Acids in Human Macrophages. Atherosclerosis (2009) 202(2):382-93. doi: 10.1016/ j.atherosclerosis.2008.05.033

17. Uhlen M, Zhang C, Lee S, Sjöstedt E, Fagerberg L, Bidkhori G, et al. A Pathology Atlas of the Human Cancer Transcriptome. Science (2017) 357 (6352). doi: 10.1126/science.aan2507

18. Naseef PP, Elayadeth-Meethal M, Anjana A, Muhas C, Kuruniyan MS. Therapeutic Potential of Induced Iron Depletion Using Iron Chelators in Covid-19. Saudi J Biol Sci (2021). doi: 10.1016/j.sjbs.2021.11.061

19. Isnard S, Lin J, Fombuena B, Ouyang J, Varin TV, Richard C, et al. eds. Repurposing Metformin in Nondiabetic People With HIV: Influence on Weight and Gut Microbiota. In: Open Forum Infectious Diseases. Montreal, QC, Canada: Oxford University Press US. 
20. Weng J-H, Koch PD, Luan H, Tu H-C, Shimada K, Ngan I, et al. Colchicine Acts Selectively in the Liver to Induce Hepatokines That Inhibit Myeloid Cell Activation. Nat Metab (2021), 1-10. doi: 10.1038/s42255-021-00366-y

21. Conte M, Ostan R, Fabbri C, Santoro A, Guidarelli G, Vitale G, et al. Human Aging and Longevity are Characterized by High Levels of Mitokines. J Gerontol: Ser A (2019) 74(5):600-7. doi: 10.1093/gerona/gly153

22. Wiklund FE, Bennet AM, Magnusson PK, Eriksson UK, Lindmark F, Wu L, et al. Macrophage Inhibitory Cytokine-1 (MIC-1/GDF15): A New Marker of All-Cause Mortality. Aging Cell (2010) 9(6):1057-64. doi: 10.1111/j.14749726.2010.00629.x

23. Adela R, Banerjee SK. GDF-15 as a Target and Biomarker for Diabetes and Cardiovascular Diseases: A Translational Prospective. J Diabetes Res (2015) 2015. doi: $10.1155 / 2015 / 490842$

24. O'Rahilly S. GDF15-from Biomarker to Allostatic Hormone. Cell Metab (2017) 26(6):807-8. doi: 10.1016/j.cmet.2017.10.017

25. Conte M, Martucci M, Chiariello A, Franceschi C, Salvioli S. eds. Mitochondria, Immunosenescence and Inflammaging: A Role for Mitokines? In: Seminars in Immunopathology. Bologna, Italy: Springer. doi: 10.1016/j.cmet.2017.10.017

26. Kim KH, Lee M-S. GDF15 as a Central Mediator for Integrated Stress Response and a Promising Therapeutic Molecule for Metabolic Disorders and NASH. Biochim Biophys Acta (BBA)-General Subj (2021) 1865(3):129834. doi: 10.1016/j.bbagen.2020.129834

27. Kang YE, Kim J-M, Lim MA, Lee SE, Yi S, Kim JT, et al. Growth Differentiation Factor 15 Is a Cancer Cell-Induced Mitokine That Primes Thyroid Cancer Cells for Invasiveness. Thyroid (2020). doi: 10.1089/ thy.2020.0034

28. Sharma R, Reinstadler B, Engelstad K, Skinner OS, Stackowitz E, Haller RG, et al. Circulating Markers of NADH-Reductive Stress Correlate With Mitochondrial Disease Severity. J Clin Invest (2021) 131(2):e136055. doi: 10.1172/JCI136055

29. Zheng H, Wu Y, Guo T, Liu F, Xu Y, Cai S. Hypoxia Induces Growth Differentiation Factor 15 to Promote the Metastasis of Colorectal Cancer via PERK-Eif $2 \alpha$ Signaling. BioMed Res Int (2020) 2020. doi: 10.1155/2020/ 5958272

30. Breit SN, Brown DA, Tsai VW-W. The GDF15-GFRAL Pathway in Health and Metabolic Disease: Friend or Foe? Annu Rev Physiol (2020) 83. doi: 10.1146/annurev-physiol-022020-045449

31. Eddy AC, Trask AJ. Growth Differentiation Factor-15 and Its Role in Diabetes and Cardiovascular Disease. Cytokine Growth Factor Rev (2020). doi: 10.1016/ j.cytogfr.2020.11.002

32. Breit SN, Brown DA, Tsai VW-W. The GDF15-GFRAL Pathway in Health and Metabolic Disease: Friend or Foe? Annu Rev Physiol (2021) 83:127-51. doi: 10.1146/annurev-physiol-022020-045449

33. Arribas JR, Thompson M, Sax PE, Haas B, McDonald C, Wohl DA, et al. Brief Report: Randomized, Double-Blind Comparison of Tenofovir Alafenamide (TAF) vs Tenofovir Disoproxil Fumarate (TDF), Each Coformulated With Elvitegravir, Cobicistat, and Emtricitabine (E/C/F) for Initial HIV-1 Treatment: Week 144 Results. JAIDS J Acquired Immune Defic Syndr (2017) 75(2):211-8. doi: 10.1097/QAI.0000000000001350

34. Min K, Liggett J, Silva G, Wu W, Wang R, Shen R, et al. NAG-1/GDF15 Accumulates in the Nucleus and Modulates Transcriptional Regulation of the Smad Pathway. Oncogene (2016) 35(3):377-88. doi: 10.1038/onc.2015.95

35. Artz A, Butz S, Vestweber D. GDF-15 Inhibits Integrin Activation and Mouse Neutrophil Recruitment Through the ALK-5/TGF- $\beta$ rii Heterodimer. Blood J Am Soc Hematol (2016) 128(4):529-41. doi: 10.1182/blood-2016-01-696617

36. Kim K-K, Lee JJ, Yang Y, You K-H, Lee J-H. Macrophage Inhibitory Cytokine-1 Activates AKT and ERK-1/2 via the Transactivation of ErbB2 in Human Breast and Gastric Cancer Cells. Carcinogenesis (2008) 29(4):70412. doi: $10.1093 /$ carcin/bgn031

37. Zhang Y, Zhang G, Liu Y, Chen R, Zhao D, McAlister V, et al. GDF15 Regulates Malat-1 Circular RNA and Inactivates Nfkb Signaling Leading to Immune Tolerogenic DCs for Preventing Alloimmune Rejection in Heart Transplantation. Front Immunol (2018) 9:2407. doi: 10.3389/fimmu.2018. 02407

38. Wang Z, He L, Li W, Xu C, Zhang J, Wang D, et al. GDF15 Induces Immunosuppression via CD48 on Regulatory $\mathrm{T}$ Cells in Hepatocellular
Carcinoma. J ImmunoTher Cancer (2021) 9(9):e002787. doi: 10.1136/jitc2021-002787

39. Aguilar-Recarte D, Barroso E, Gumà A, Pizarro-Delgado J, Peña L, Ruart M, et al. GDF15 Mediates the Metabolic Effects of Ppar $\beta / \delta$ by Activating AMPK. Cell Rep (2021) 36(6):109501. doi: 10.1016/j.celrep.2021.109501

40. Patsalos A, Halasz L, Medina-Serpas MA, Berger WK, Daniel B, Tzerpos P, et al. A Growth Factor-Expressing Macrophage Subpopulation Orchestrates Regenerative Inflammation via GDF-15. J Exp Med (2022) 219(1). doi: $10.1084 / \mathrm{jem} .20210420$

41. McCarville J, Ayres J. Disease Tolerance: Concept and Mechanisms. Curr Opin Immunol (2018) 50:88-93. doi: 10.1016/j.coi.2017.12.003

42. Sun Y, Milne S, Jaw JE, Yang CX, Xu F, Li X, et al. BMI is Associated With FEV 1 Decline in Chronic Obstructive Pulmonary Disease: A Meta-Analysis of Clinical Trials. Respir Res (2019) 20(1):1-10. doi: 10.1186/s12931-0191209-5

43. Swanepoel R, Leman PA, Burt FJ, Zachariades NA, Braack L, Ksiazek TG, et al. Experimental Inoculation of Plants and Animals With Ebola Virus. Emerg Infect Dis (1996) 2(4):321. doi: 10.3201/eid0204.960407

44. Watanabe S, Masangkay JS, Nagata N, Morikawa S, Mizutani T, Fukushi S, et al. Bat Coronaviruses and Experimental Infection of Bats, the Philippines. Emerg Infect Dis (2010) 16(8):1217. doi: 10.3201/eid1608.100208

45. Irving AT, Ahn M, Goh G, Anderson DE, Wang L-F. Lessons From the Host Defences of Bats, a Unique Viral Reservoir. Nature (2021) 589(7842):363-70. doi: 10.1038/s41586-020-03128-0

46. Al-Mudares F, Reddick S, Ren J, Venkatesh A, Zhao C, Lingappan K. Role of Growth Differentiation Factor 15 in Lung Disease and Senescence: Potential Role Across the Lifespan. Front Med (2020) 7:919. doi: 10.3389/fmed. 2020.594137

47. Zhang $\mathrm{Y}$, Jiang M, Nouraie M, Roth MG, Tabib T, Winters S, et al. GDF15 Is an Epithelial-Derived Biomarker of Idiopathic Pulmonary Fibrosis. Am J Physiol-Lung Cell Mol Physiol (2019) 317(4):L510-L21. doi: 10.1152/ ajplung.00062.2019

48. Herter JM, Kraft F, Van Aken H, Meersch M, Zarbock A, Rossaint J. GDF-15 Prevents Ventilator-Induced Lung Injury by Inhibiting the Formation of Platelet-Neutrophil Aggregates. Thromb Haemost (2015) 114(2):434. doi: 10.1160/TH14-12-1060

49. Verhamme F, Seys L, De Smet E, Provoost S, Janssens W, Elewaut D, et al. Elevated GDF-15 Contributes to Pulmonary Inflammation Upon Cigarette Smoke Exposure. Mucosal Immunol (2017) 10(6):1400-11. doi: 10.1038/ mi.2017.3

50. Hammad H, Lambrecht BN. Wnt and Hippo Pathways in Regulatory T Cells: A NOTCH Above in Asthma. Nat Immunol (2020) 21(11):1313-4. doi: 10.1038/s41590-020-0797-z

51. Albertoni M, Shaw PH, Nozaki M, Godard S, Tenan M, Hamou M-F, et al. Anoxia Induces Macrophage Inhibitory Cytokine-1 (MIC-1) in Glioblastoma Cells Independently of P53 and HIF-1. Oncogene (2002) 21(27):4212-9. doi: 10.1038/sj.onc. 1205610

52. Voynow JA, Rubin BK. Mucins, Mucus, and Sputum. CHEST (2009) 135 (2):505-12. doi: 10.1378/chest.08-0412

53. Eisner MD, Anthonisen N, Coultas D, Kuenzli N, Perez-Padilla R, Postma D, et al. An Official American Thoracic Society Public Policy Statement: Novel Risk Factors and the Global Burden of Chronic Obstructive Pulmonary Disease. Am J Respir Crit Care Med (2010) 182(5):693-718. doi: 10.1164/ rccm.200811-1757ST

54. Nickel N, Jonigk D, Kempf T, Bockmeyer CL, Maegel L, Rische J, et al. GDF15 is Abundantly Expressed in Plexiform Lesions in Patients With Pulmonary Arterial Hypertension and Affects Proliferation and Apoptosis of Pulmonary Endothelial Cells. Respir Res (2011) 12(1):1-11. doi: 10.1186/ 1465-9921-12-62

55. Odler B, Foris V, Gungl A, Müller V, Hassoun PM, Kwapiszewska G, et al. Biomarkers for Pulmonary Vascular Remodeling in Systemic Sclerosis: A Pathophysiological Approach. Front Physiol (2018) 9:587. doi: 10.3389/ fphys.2018.00587

56. Zhang Y, Jiang W, Wang L, Lingappan K. Sex-Specific Differences in the Modulation of Growth Differentiation Factor 15 (GDF15) by Hyperoxia In Vivo and In Vitro: Role of Hif-1 $\alpha$. Toxicol Appl Pharmacol (2017) 332:8-14. doi: 10.1016/j.taap.2017.07.016 
57. Cheng K, Shi J, Liu Z, Jia Y, Qin Q, Zhang H, et al. A Panel of Five Plasma Proteins for the Early Diagnosis of Hepatitis B Virus-Related Hepatocellular Carcinoma in Individuals at Risk. EBioMedicine (2020) 52:102638. doi: 10.1016/j.ebiom.2020.102638

58. Halim MH, Abdulla NA, Kamel A, Abd El Maksoud N, Ragab HM. Significance of Growth Differentiation Factor 15 in Chronic HCV Patients. J Genet Eng Biotechnol (2017) 15(2):403-7. doi: 10.1016/j.jgeb.2017.08.004

59. Lee ES, Kim SH, Kim HJ, Kim KH, Lee BS, Ku BJ. Growth Differentiation Factor 15 Predicts Chronic Liver Disease Severity. Gut Liver (2017) 11(2):276. doi: $10.5009 /$ gnl 16049

60. Liu X, Chi X, Gong Q, Gao L, Niu Y, Chi X, et al. Association of Serum Level of Growth Differentiation Factor 15 With Liver Cirrhosis and Hepatocellular Carcinoma. PloS One (2015) 10(5):e0127518. doi: 10.1371/journal. pone. 0127518

61. Chen J, Dai W, Zhu C, Liu H, Li Y, Zhang P. Circulating Levels of Growth Differentiation Factor 15 and Sex Hormones in Male Patients With HBVAssociated Hepatocellular Carcinoma. Biomed Pharmacother (2020) 121:109574. doi: 10.1016/j.biopha.2019.109574

62. Krawczyk M, Zimmermann S, Hess G, Holz R, Dauer M, Raedle J, et al. Panel of Three Novel Serum Markers Predicts Liver Stiffness and Fibrosis Stages in Patients With Chronic Liver Disease. PloS One (2017) 12(3):e0173506. doi: 10.1371/journal.pone.0173506

63. Keser T, Gornik I, Vučković F, Selak N, Pavić T, Lukić E, et al. Increased Plasma N-Glycome Complexity Is Associated With Higher Risk of Type 2 Diabetes. Diabetologia (2017) 60(12):2352-60. doi: 10.1007/s00125-017-4426-9

64. Wu Q, Jiang D, Schaefer NR, Harmacek L, O’Connor BP, Eling TE, et al. Overproduction of Growth Differentiation Factor 15 Promotes Human Rhinovirus Infection and Virus-Induced Inflammation in the Lung. Am J Physiol-Lung Cell Mol Physiol (2018) 314(3):L514-L27. doi: 10.1152/ajplung. 00324.2017

65. Li H, Tang D, Chen J, Hu Y, Cai X, Zhang P. The Clinical Value of GDF15 and Its Prospective Mechanism in Sepsis. Front Immunol (2021) 12. doi: 10.3389/ fimmu.2021.710977

66. Santos I, Colaço HG, Neves-Costa A, Seixas E, Velho TR, Pedroso D, et al. CXCL5-Mediated Recruitment of Neutrophils Into the Peritoneal Cavity of Gdf15-Deficient Mice Protects Against Abdominal Sepsis. Proc Natl Acad Sci (2020) 117(22):12281-7. doi: 10.1073/pnas.1918508117

67. Chen L, Qiao L, Bian Y, Sun X. GDF15 Knockdown Promotes ErastinInduced Ferroptosis by Decreasing SLC7A11 Expression. Biochem Biophys Res Commun (2020) 526(2):293-9. doi: 10.1016/j.bbrc.2020.03.079

68. de Guadiana Romualdo LG, Mulero MDR, Olivo MH, Rojas CR, Arenas VR, Morales MG, et al. Circulating Levels of GDF-15 and Calprotectin for Prediction of in-Hospital Mortality in COVID-19 Patients: A Case Series. J Infect (2020). doi: 10.1016/j.jinf.2020.08.010

69. Giron LB, Dweep H, Yin X, Wang H, Damra M, Goldman AR, et al. Severe COVID-19 Is Fueled by Disrupted Gut Barrier Integrity. medRxiv (2020). doi: 10.1101/2020.11.13.20231209

70. Myhre PL, Prebensen C, Strand H, Røysland R, Jonassen CM, Rangberg A, et al. Growth Differentiation Factor 15 Provides Prognostic Information Superior to Established Cardiovascular and Inflammatory Biomarkers in Unselected Patients Hospitalized With COVID-19. Circulation (2020) 142 (22):2128-37. doi: 10.1161/CIRCULATIONAHA.120.050360

71. Notz Q, Schmalzing M, Wedekink F, Schlesinger T, Gernert M, Herrmann J, et al. Pro-And Anti-Inflammatory Responses in Severe COVID-19-Induced Acute Respiratory Distress Syndrome-An Observational Pilot Study. Front Immunol (2020) 11. doi: 10.3389/fimmu.2020.581338

72. Wallentin L, Lindbäck J, Eriksson N, Hijazi Z, Eikelboom JW, Ezekowitz MD, et al. Angiotensin-Converting Enzyme 2 (ACE2) Levels in Relation to Risk Factors for COVID-19 in Two Large Cohorts of Patients With Atrial Fibrillation. Eur Heart J (2020). doi: 10.1093/eurheartj/ehaa697

73. Gisby J, Clarke CL, Medjeral-Thomas N, Malik TH, Papadaki A, Mortimer PM, et al. Longitudinal Proteomic Profiling of Dialysis Patients With COVID19 Reveals Markers of Severity and Predictors of Death. Elife (2021) 10: e64827. doi: 10.7554/eLife.64827.sa2

74. Rochette L, Zeller M, Cottin Y, Vergely C. GDF15: An Emerging Modulator of Immunity and a Strategy in COVID-19 in Association With Iron Metabolism. Trends Endocrinol Metab (2021). doi: 10.1016/j.tem.2021.08.011
75. Romero Starke K, Petereit-Haack G, Schubert M, Kämpf D, Schliebner A, Hegewald J, et al. The Age-Related Risk of Severe Outcomes Due to COVID-19 Infection: A Rapid Review, Meta-Analysis, and MetaRegression. Int J Environ Res Public Health (2020) 17(16):5974. doi: 10.3390/ijerph17165974

76. Fajgenbaum DC, June CH. Cytokine Storm. N Engl J Med (2020) 383 (23):2255-73. doi: 10.1056/NEJMra2026131

77. Chatenoud L, Ferran C, Bach J-F. The Anti-CD3-Induced Syndrome: A Consequence of Massive In Vivo Cell Activation. Superantigens: Springer (1991) p:121-34. doi: 10.1007/978-3-642-50998-8_9

78. Kash JC, Tumpey TM, Proll SC, Carter V, Perwitasari O, Thomas MJ, et al. Genomic Analysis of Increased Host Immune and Cell Death Responses Induced by 1918 Influenza Virus. Nature (2006) 443(7111):578-81. doi: 10.1038/nature05181

79. Pechous RD, Sivaraman V, Price PA, Stasulli NM, Goldman WE. Early Host Cell Targets of Yersinia Pestis During Primary Pneumonic Plague. PloS Pathog (2013) 9(10):e1003679. doi: 10.1371/journal.ppat.1003679

80. Picchianti Diamanti A, Rosado MM, Pioli C, Sesti G, Laganà B. Cytokine Release Syndrome in COVID-19 Patients, a New Scenario for an Old Concern: The Fragile Balance Between Infections and Autoimmunity. Int J Mol Sci (2020) 21(9):3330. doi: 10.3390/ijms21093330

81. Hou YJ, Okuda K, Edwards CE, Martinez DR, Asakura T, Dinnon KHIII, et al. SARS-CoV-2 Reverse Genetics Reveals a Variable Infection Gradient in the Respiratory Tract. Cell (2020). doi: 10.1016/j.cell.2020.05.042

82. Huang KJ, Su IJ, Theron M, Wu YC, Lai SK, Liu CC, et al. An Interferon- $\gamma$ Related Cytokine Storm in SARS Patients. J Med Virol (2005) 75(2):185-94. doi: 10.1002/jmv.20255

83. Gustine JN, Jones D. Immunopathology of Hyperinflammation in COVID-19. Am J Pathol (2020). doi: 10.1016/j.ajpath.2020.08.009

84. Chen L, Zheng S. Understand Variability of COVID-19 Through Population and Tissue Variations in Expression of SARS-CoV-2 Host Genes. Inf Med Unlocked (2020), 100443. doi: 10.1016/j.imu.2020.100443

85. Sharif-Askari NS, Sharif-Askari FS, Mdkhana B, Alsayed HAH, Alsafar H, Alrais ZF, et al. Upregulation of Oxidative Stress Gene Markers During SARSCOV-2 Viral Infection. Free Radical Biol Med (2021) 172:688-98. doi: 10.1016/j.freeradbiomed.2021.06.018

86. Buchrieser J, Dufloo J, Hubert M, Monel B, Planas D, Rajah MM, et al. Syncytia Formation by SARS-CoV-2-Infected Cells. EMBO J (2020):e106267. doi: $10.15252 / \mathrm{embj} .2020106267$

87. Mazagova M, Buikema H, Landheer SW, Vavrinec P, Buiten Av, Henning RH, et al. Growth Differentiation Factor 15 Impairs Aortic Contractile and Relaxing Function Through Altered Caveolar Signaling of the Endothelium. Am J Physiol-Heart Circulatory Physiol (2013) 304(5):H709-H18. doi: 10.1152/ajpheart.00543.2012

88. Rochette L, Zeller M, Cottin Y, Vergely C. Redox Functions of Heme Oxygenase-1 and Biliverdin Reductase in Diabetes. Trends Endocrinol Metab (2018) 29(2):74-85. doi: 10.1016/j.tem.2017.11.005

89. Finkenstedt A, Bianchi P, Theurl I, Vogel W, Witcher DR, Wroblewski VJ, et al. Regulation of Iron Metabolism Through GDF15 and Hepcidin in Pyruvate Kinase Deficiency. Br J Haematol (2009) 144(5):789-93. doi: 10.1111/j.1365-2141.2008.07535.x

90. Huang Y, Lei Y, Liu R, Liu J, Yang G, Xiang Z, et al. Imbalance of Erythropoiesis and Iron Metabolism in Patients With Thalassemia. Int J Med Sci (2019) 16(2):302. doi: 10.7150/ijms.27829

91. Nalado AM, Olorunfemi G, Dix-Peek T, Dickens C, Khambule L, Snyman T, et al. Hepcidin and GDF-15 are Potential Biomarkers of Iron Deficiency Anaemia in Chronic Kidney Disease Patients in South Africa. BMC Nephrol (2020) 21(1):1-10. doi: 10.1186/s12882-020-02046-7

92. Nemeth E, Ganz T. The Role of Hepcidin in Iron Metabolism. Acta Haematol (2009) 122(2-3):78-86. doi: 10.1159/000243791

93. Tanno T, Bhanu NV, Oneal PA, Goh S-H, Staker P, Lee YT, et al. High Levels of GDF15 in Thalassemia Suppress Expression of the Iron Regulatory Protein Hepcidin. Nat Med (2007) 13(9):1096-101. doi: 10.1038/nm1629

94. Theurl I, Finkenstedt A, Schroll A, Nairz M, Sonnweber T, Bellmann-Weiler $\mathrm{R}$, et al. Growth Differentiation Factor 15 in Anaemia of Chronic Disease, Iron Deficiency Anaemia and Mixed Type Anaemia. Br J Haematol (2010) 148 (3):449-55. doi: 10.1111/j.1365-2141.2009.07961.x 
95. Jiang F, Yu W-J, Wang X-H, Tang Y-T, Guo L, Jiao X-Y. Regulation of Hepcidin Through GDF-15 in Cancer-Related Anemia. Clin Chim Acta (2014) 428:14-9. doi: 10.1016/j.cca.2013.10.015

96. Qiu Y, Cao Y, Cao W, Jia Y, Lu N. The Application of Ferroptosis in Diseases. Pharmacol Res (2020) 159:104919. doi: 10.1016/j.phrs.2020.104919

97. Fishbane S, Spinowitz B. Update on Anemia in ESRD and Earlier Stages of CKD: Core Curriculum 2018. Am J Kidney Dis (2018) 71(3):423-35. doi: 10.1053/j.ajkd.2017.09.026

98. Łukaszyk E, Łukaszyk M, Koc-Żórawska E, Tobolczyk J, Bodzenta-Łukaszyk A, Małyszko J. Iron Status and Inflammation in Early Stages of Chronic Kidney Disease. Kidney Blood Pressure Res (2015) 40(4):366-73. doi: 10.1159/ 000368512

99. Dalamaga M, Karampela I, Mantzoros CS. Commentary: Could Iron Chelators Prove to be Useful as an Adjunct to COVID-19 Treatment Regimens? Metabolism (2020) 108:154260. doi: 10.1016/j.metabol.2020.154260

100. Mahalmani V, Sarma P, Prakash A, Medhi B. Role of Iron Chelators in Mucormycosis. Indian J Pharmacol (2021) 53(4):261. doi: 10.4103/ ijp.ijp_604_21
Conflict of Interest: The authors declare that the research was conducted in the absence of any commercial or financial relationships that could be construed as a potential conflict of interest.

Publisher's Note: All claims expressed in this article are solely those of the authors and do not necessarily represent those of their affiliated organizations, or those of the publisher, the editors and the reviewers. Any product that may be evaluated in this article, or claim that may be made by its manufacturer, is not guaranteed or endorsed by the publisher.

Copyright () 2022 Ahmed, Isnard, Berini, Lin, Routy and Royston. This is an openaccess article distributed under the terms of the Creative Commons Attribution License (CC BY). The use, distribution or reproduction in other forums is permitted, provided the original author(s) and the copyright owner(s) are credited and that the original publication in this journal is cited, in accordance with accepted academic practice. No use, distribution or reproduction is permitted which does not comply with these terms. 